\title{
CCJR ANNUAL MEETING PROCEEDING
}

\author{
Reflections on Reflections: \\ Jesus, Judaism, and Jewish-Christian Relations
}

Amy-Jill Levine, Vanderbilt University

For the October 2012 CCJR Plenary, Ruth Langer and Philip Cunningham convened a session to address the question, "Why is Jesus' Jewishness Important?" As Professor Cunningham explained, the goal was for Professor Arthur J. Dewey and me to "give parallel presentations that will serve as the basis for follow-up Question and Answer and discussion with CCJR members and the local public."

For the panel, I offered three broad questions; my intention was not to resolve issues, but to formulate them in a way that would prompt discussion.

1. Why has the relationship between Jesus and Judaism caught popular as well as scholarly imagination, with multiple volumes authored by such major scholars as John Meier, James Charlesworth, Peter Schäfer, Daniel Boyarin, the collection edited by Zev Garber, and numerous churches and synagogues sponsoring programs/lectures? I admit to participating in this process myself.

2. How are we defining "Jewishness" and "important"?

3. What are the implications of Jesus' Jewishness for Jewish/Christian relations?

The result was a rich conversation with the people in attendance; it was also, for me, an opportunity to develop my own thoughts in dialogue with Professor Dewey. The remarks below are the result of that gathering. 


\section{Jesus, Judaism, and the Popular Imagination}

The interest in Jesus among the Jews, from modern Orthodox through secular humanist, is at an unprecedented high. This fact is demonstrated on the academic level by the 51 Jewish contributors to the Jewish Annotated New Testament; it is apparent on the popular level by the growing number of joint church/synagogue scholar-in-residence programs on Jesus in his Jewish context, the increasing quantity of articles about Jesus appearing in Jewish magazines, and the many recent books on Jesus, both popular and scholarly, written by Jewish authors. Jews are not alone in this interest: Jesus' Jewish context is also of interest to many Roman Catholics, Evangelicals, and liberal Protestants.

And yet, Professor Dewey's comment, “...for many, Jesus is so removed from history that he cannot be imagined as Jewish," is, I fear, closer to the consensus view than the optimistic image that I want to hold. He is correct: numerous people do not know that Jesus was a Jew; many, both Jewish and Christian, do not want to acknowledge this fact. Still present are claims that Jesus was an Aryan, or that he came to do away with Judaism, or that he learned his wisdom from Buddhist monks or Hindu scholars or Egyptian priests or sub-Saharan shamans or extra-terrestrials...that is, from anyone but his fellow Jews or from the Scriptures of Israel. Bigotry and ignorance go hand in hand.

As for those who do see an import in the connection between Jesus and Judaism, the question is why. Here are a few suggestions.

From the Jewish side, first, there is pride in reclaiming Jesus as one of ours. If we Jews can celebrate other notable Jews-Sigmund Freud, Henri Bergson, Boris Pasternak, Nadine Gordimer, Albert Einstein, Elena Kagan and Ruth Bader Ginsberg, 20\% of the Nobel Prize winners, everyone listed in each of Adam Sandler's "Hannukah Songs"-then surely we can list Jesus. This interest in Jesus and the New Testament is 
quite a shift from a generation or so, when Jesus was seen as the apostate and the NT was deliberately avoided.

Second, Jesus specifically and much of the New Testament in general provide Jews with information on our history. Our religious educational programs typically go from the Maccabees in the second century BCE to the Mishnah (to appeal here to the title of Shaye Cohen's classic study), with no attention to the first century aside from possible quick mentions of Yavneh (Jamnia) or Josephus. The Gospels, along with Josephus, the Dead Sea Scrolls, and archaeological finds, are among our best sources for reconstructing Jewish life in first-century Galilee and Judea. They tell us about synagogue gatherings and Sabbath observance, women's roles as independent householders, relations with Rome, tenant farming and Passover celebrations, and so much more.

Third, increasing numbers of Jews are interested in Jesus for apologetic and sometimes polemical purposes. Some want information to counter the false and ugly stereotypes about Jesus' Jewish context not infrequently promulgated by misinformed Christians; others seek ammunition to counter Christian missionaries.

Fourth, and in my view the most encouraging when it comes to interfaith relations, some Jews are genuinely curious about the figure so central to the lives of their Christian friends. Not only to admit to an interest in the historical Jesus but also to seek information about him indicates Jewish comfort with our own identities, respect for the beliefs of our Christian neighbors, and the refusal to be cowed by the few ultra-Orthodox thinkers who would restrict knowledge.

For traditional Roman Catholics, interest in the Jesus' Jewish context is encouraged not only by the close relations developed personally between Catholics and Jews, but also by ecclesial prompts, both from the Vatican and from the U.S. Bishops. For example, this interest is part of the larger project promoted by the 1943 Encyclical Divinu Afflante Spiritu of 
opening up Catholic biblical study to higher criticism. Understanding Jesus and the Gospel texts is necessarily enhanced by historical-critical observations. Since Jesus and the Gospels come from a time before any formal separation between Judaism and Christianity or Synagogue and Church, knowledge of Christian origins necessary requires attention to Jesus' Jewish context and to the Gospels' depictions of Jews and Judaism.

Roman Catholic interest in Jesus as a Jew is also part of the larger movement in Catholic-Jewish relations, a grace [that is exactly the right word] signaled by Vatican II's Nostra Aetate and continued in such texts as the U.S. Conference of Catholic Bishops' 1988 “God's Mercy Endures Forever: Guidelines on the Presentation of Jews and Judaism in Catholic Preaching." This document offers considered ecclesial warrant for locating Jesus within his Jewish context: it notes "The strongly Jewish character of Jesus' teaching and that of the primitive Church" which "was culturally adapted by the growing Gentile majority and later blurred by controversies alienating Christianity from emerging rabbinic Judaism at the end of the first century." Lamenting this alienation, it insists, "The Christian proclamation of the saving deeds of the One God through Jesus was formed in the context of Second Temple Judaism and cannot be understood thoroughly without that context."

The document then provides examples of how that context influences praxis and theology. It begins by remarking, "Jesus was observant of the Torah (e.g., in the details of his circumcision and purification given in Lk 2:21-24)." On this point, Mary and Joseph are in fact the observant ones; the infant Jesus had little choice in his circumcision. However the notice does show a connection between Jewish and Catholic practice. The remark implicitly adverts to the practice of infant baptism: Jesus is initiated into his community by his parents, the priests in the Temple, and the community members present. Jesus, Mary, and Joseph participated in the practices and not just the beliefs of Judaism. 
Continuing, the bishops mention, "Jesus shared with the Pharisees a number of distinctive doctrines: the resurrection of the body; forms of piety such as almsgiving, daily prayer, and fasting; the liturgical practice of addressing God as Father; and the priority of the love commandment." They observe, "Jesus taught in the synagogues (see Mt 4:23 and 9:35; Lk 4:15-18; Jn 18:20) and in the Temple, which he frequented, as did the disciples even after the Resurrection (see Acts 2:46; 3:lff)." Notable in these descriptions again is the concern for action as well as belief, for practice as well as doctrine.

Finally, the bishops remark that Jesus "extolled respect for [Torah] (see Mt 5:17-20), and he invited obedience to it (see Mt 8:4)." It is on Jesus' interpretation of Torah that Jews and Christians today have much to discuss. Whereas Jews, Roman Catholics, and all Protestants have the common root of the Hebrew text (Eastern Orthodoxy, which follows the Septuagint, is a separate issue), we have distinct interpretations. The USCCB correctly adds, "While Jesus showed uniqueness and authority in his interpretation of God's word in the Torah-in a manner that scandalized some Jews and impressed others--he did not oppose it, nor did he wish to abrogate it....” Rabbinic Judaism understands that the study and practice of Torah are community concerns; an individual cannot dictate either orthodoxy or orthopraxy. Thus, Jesus' arrogation to himself of the right to interpret texts on his own authority would not have pleased some of his contemporaries.

Nevertheless, the interpretations Jesus offers are Jewish readings, consistent with the Rabbinic practice of "building a fence" about the Law. To "You shall not murder," Jesus added loving enemies. To "You shall not commit adultery," he condemned lust. To "Do not swear falsely," he said, "Let your word be 'Yes, Yes' or 'No, No'; anything more than this comes from the evil one" (Matthew 5:37). Jesus also uses Rabbinic exegetical forms, such as the qal v'homer (from the lesser to the greater) argument (e.g., Matthew 12:11-12, "Suppose one of you has only one sheep and it falls into a pit on the Sabbath; will you not lay hold of it and lift it out? How 
much more valuable is a human being than a sheep. So it is permitted to do good on the Sabbath") and arguing from precedent (e.g., Mark 2:25-27, where he justifies plucking heads of grain on the Sabbath by [a problematic] appeal to King David's actions in the temple at Nob [1 Samuel 21]).

For Evangelicals, Jesus' Jewishness is recently coming to the fore for various rationales. For some, it is part of the greater interest in (re-)claiming the "Historical Jesus" from the liberals who want to strip out Christological confession and miraculous acts. Seeking to demonstrate how the Christ of faith makes sense in a first-century Jewish context, some Evangelical biblical scholars are now utilizing the criteria of authenticity, while many scholars to the left are realizing that the criteria do not work.

Next, some Evangelical Christians as well as members of some messianic Jewish groups have recognized that emphasizing Jesus the Jew facilitates missionary work: if Jesus can be shown as fully Jewish, so the argument goes, then Jews today can be fully Jewish and accept Jesus as Lord and Savior. For yet others, interest in Jesus' Jewish context is part of the broader phenomenon usually called "Christian Zionism." The phenomenon is not restricted to Dispensationalist views; it has various motivations, from the interest in protecting America's ally in the Middle East to an "America First" theology that regards the promises to Abraham in Genesis 12:3 ("I will bless those who bless you...”) to be related to support for the Jewish State, to a recognition that Israel is the national homeland of the Jewish people.

Concerning liberal Protestants and others with comparably lower Christologies, interest in Jesus's Jewishness can serve as a means to deflect high christological claims. While Evangelicals find Jesus the Jew is consistent with Jesus the divine Son of God, for some liberals, Jesus the Jew is the human Jesus: the teacher, healer, exorcist, social critic, peasant organizer, and so forth, but not the second person of the Trinity. 
Whereas this emphasis on the human Jesus, embedded in his social context, should have promoted a generous, appreciative reading of Jesus' Jewish context, at times the opposite is the case. Here Professor Dewey's observations on the category of "difference" or "uniqueness" are spot on. If one begins with a high Christology-Jesus is divine, his mother was a virgin prepartum, in partu, and post-partum, he rose from the dead and ascended into heaven-then he's "different," indeed, divine. But if he's just a very interesting teacher, there is no reason to worship him. By constructing Jesus' Jewish context as epitomizing what is bad in today's world and then locating Jesus as standing against it, some New Testament readers makes Jesus both "different" and relevant.

Thus Jesus is the feminist amid a Judaism that, as former President Jimmy Carter states in his Bible tapes, resembles the Taliban; Jesus is a Caesar Chavez within a Judaism seen to view the rich as pious and the poor as sinful; Jesus is a Martin Luther preaching against what some biblical scholars have taken to calling the "Temple Domination System"; he is a Martin Luther King, Jr. preaching against a presumed Jewish xenophobia; he is a Saul Alinksy-who knew?-against Pharisaic retainers who have a hold on taxes and tithes (that Pharisees were neither Temple agents nor revenue receivers is irrelevant to the construct); Jesus is the Palestinian activist "crucified" by the Jews. The mantra that Jesus came to replace a "system of holiness" or "system of purity" with a "system of compassion" is sometimes heard, with few noting that holiness/purity and compassion are not antonyms. Still popular is the view that Jesus invented calling God "Abba," that "abba" means "daddy," and that it is a designation all other Jews would find blasphemous. The goals underlying these various moves-proclaiming justice, promoting an intimate theology, etc.-are all worthy; the rhetoric however relies on anti-Jewish stereotypes.

These readers do not deny Jesus' Jewishness, but they do narrowly circumscribe it. For them, Jesus' Jewishness is grounded in the liberating word of the prophets and the social justice of Deuteronomy. It is divorced, however, from halakhic practice, 
synagogue attendance, or Temple sacrifice. The underlying message is that the Scriptures of Israel are usable resources, but somehow everyone in Second Temple Judaism save Jesus misunderstood them (see 2 Corinthians 3:14-15).

This view of Jesus in distinction to his Jewish context, and the attendant negative categorizing of that context, is in part the legacy of centuries of Protestant, Anti-Catholic exegesis. Constructions of "works-righteousness" undermine attention to Jesus' halakhic fidelity as well as that of his Jewish followers. Undermined as well is the recognition that halakhah promotes the very multiculturalism that many of these critics would commend: following Torah allows Jews to celebrate their tradition ever hour of every day by promoting sanctification of the body even as it helps them in resisting assimilation (as archaeological evidence of stone vessels, ritual baths, and lack of pig bones in Jewish lower Galilee attest).

It is on this question of Jesus' distinctiveness that Professor Dewey's comments prompt well-taken warnings. Professor Dewey observes that in Roman thought, "To call someone a 'son of God' meant that one was in some way 'different' from others." I do wonder if this "Roman thought" or broadly "Gentile" thought that the USCCB document laments influences the tendency to take Jesus out of his Jewish context and render him as different. In Second Temple Jewish thought broadly construed, the designation "child of God" need not indicate a divine being. As Jesus states in Matthew 5:9, "Blessed are the peacemakers, for they will be called children [literally, "sons"] of God." Paul states, "For all who are led by the Spirit of God are children of God" (Romans 8:14; see also 8:16, 19, 21; 9:8; Galatians 3:26; Philippians 2:15). Even Luke, the most goyyish of the Gospels, makes the point in Jesus' genealogy, for Jesus "was the son (as was thought) of Joseph son of Heli.... of Enos, [son] of Seth, [son] of Adam, [son] of God” (Luke 3:23-38). 


\section{Definitions of "Jewishness"}

The question "who is a Jew" was a problem in antiquity, and it remains a problem today. Scholars have sometimes set up constructs of what Jews think and do, and then checked to see whether Jesus fit the predetermined definitions. For example, the Jesus-seminar consensus of a non-apocalyptic Jesus was seen by some scholars as a de-Judaizing of Jesus; in these critiques, apocalyptic eschatology is a necessary marker of Second Temple Jewish thought. We have more or less gotten past this view that all Jews were eschatological, or that a noneschatological Jesus is a non-Jewish Jesus. Whereas I do see Jesus as an apocalyptic prophet, I also see him as a teacher of profound ethics, for the two are not exclusive, as the pages of apocalyptic/wisdom texts ranging from 1 Enoch and Daniel to Revelation, 4 Ezra, and 2 Baruch demonstrate. But I do agree with Professor Dewey that Jesus may be among the early Jewish stand-up comics, in a line begun much earlier, with the writers of parts of the Torah, Nevi'im, and Ketuvim, with special nods to the authors of Jonah, Ruth, and Esther.

As I understand Jesus, his apocalyptic sensibilities are connected to the meaning his death had for himself and for his followers. Professor Dewey remarks, "not all of Jesus' followers were concerned with determining a meaning for his death" and cites in support the hypothetical Q document, the Didache, and the Gospel of Thomas. Yet he also notes that Jews of the time were concerned with the meaning of death, and especially with understanding the implications of martyrdom. Perhaps Jesus did think his death would be efficacious in redeeming people from sin or in bringing about the Kingdom he proclaimed; these would be views well within the Jewish mainstream. Perhaps those people who compiled Q-if Q exists (I think it does, but I would not bet on it)-also thought deeply about Jesus' death, just as the people who compiled the book of Proverbs and the Wisdom of Solomon knew of Torah. A text is not a community; a single book does not tell us the ethos of its readers. 
Notable for the purposes of the CCJR meeting is that Professor Dewey and I disagree on our understandings of both Jesus and the people responsible for preserving some of his sayings, but the disagreement is not based on a restricted view of early Judaism.

Other scholars, operating with a somewhat restricted view of what early Judaism could accommodate, concluded that the words of Institution, the Eucharist, must have come from pagan tradition, because no Jew would have analogized human flesh and blood to bread and wine and encouraged its consumption. We have gotten past this as well. Jews, including Jesus, are not exempt from using provocative images. That some found the language distasteful (see John 6:60) does not make the language ahistorical.

Or scholars concluded that Jesus could not have proclaimed himself the messiah, or related to God, because that would have compromised Jewish monotheism. But we realize today how fluid monotheism was, and how Jewish thought in the first century-if not in the fifth-could accommodate the divine descending to earth as well as the traditions which did not hold the messiah to be divine. Today the Gospel of John is increasingly seen as containing substantial "historical Jesus" material. I suspect Professor Dewey and I would disagree here as well, but again, the disagreements are not based on a limited view of early Judaism.

For a fairly small contingent in the biblical studies guild, Jesus is not a "Jew" at all, for they insist that the term "Jew" has no meaning prior to the codification of the Talmud. These readers prefer that the Greek term Ioudaios, the New Testament term normally translated "Jew" (as in the titulus on the cross, "King of the Jews" [Matthew 27:37; Mark 15:26; Luke 23:38; John 19:19]) be translated "Judean" and so receive a geographical and ethnic rather than religious emphasis. The translation is viable. 
Whether the translation is historically warranted is another question. If we translate Ioudaios as "Judean," we divorce Jesus from Judaism in two ways. First, we eliminate Jews from the Bible and thus create a judenrein text, a text purified of Jews (yes, the German is overdetermined). Thus neither Jesus nor anyone else in the Bible is a "Jew." We then note that Jesus was not a Judean, but a Galilean. As Professor Dewey may remember, since I remarked on this point at the one meeting of the Jesus seminar I attended, I was curious about the use of the translation "Judean" instead of "Jew" in popular culture, so back around 2006 I googled "Jesus, Jew, and Judean" to see what I would find. The result: websites for KKK and neo-Nazi sympathizers. Take Jews out of the New Testament and make Jesus a Galilean rather than a Judean, and the next step is to make him an Aryan. I do not find this helpful. That many scholars who render Ioudaios as "Judean" also often refer to Judea and the Galilee as "Palestine," a non-biblical term with its own host of overdetermined implications, creates a whole other set of problems.

Today, the greater problem in the church, and to some extent in scholarship, is that while pretty much everyone agrees that Jesus was a Jew (although on occasion is heard the plaintive comment, "surely not the blessed mother"), there remains a lack of agreement, or even awareness of what that label "Jew" means. To characterize Jesus as a Jew should mean more than simply an ethnic definition. Jesus was a Jew not only by descent, but also in practice, in discourse, and in his reception by his fellow Jews.

\section{Definitions of Important}

The term "important" is-like the term "significant"-empty of meaning without explanation. Important to whom, for what? If we are discussing Jesus as the second person of the Trinity or as the image of the divine on earth, then I would not privilege his Jewish identity any more than I would privilege his being male or Galilean. However, if we are discussing the Jesus of history, then his Jewishness is central to his life. He is a 
Galilean Jew and not a Gentile Roman; his "spiritual formation" is in the context of the Scriptures of Israel as interpreted by his fellow Jews and not Stoic philosophy or Homeric verse; his message, although adaptable beyond his context, is framed in Jewish idioms directed to Jewish people.

Jesus' Jewishness is also "important" in Christian salvation history. As Paul avers in Romans 9:4-5, "They are Israelites, and to them belong the adoption, the glory, the covenants, the giving of the law, the worship, and the promises; to them belong the patriarchs, and from them, according to the flesh, comes the Messiah, who is over all, God blessed forever. Amen.” Theologically, Judaism and Christianity both claim to be historical religions and to proclaim a God who self-reveals in history. That means that Jesus' Jewishness is an indication of divine fidelity.

For Jewish-Christian relations-which moves us into our final topic, the connection between Jesus and Judaism is "important"--indeed, essential. Were Jesus not a Jew, matters would be substantially different, probably over the past 2,000 years. I am not, however, interested in alternative histories, and I see little reason to speculate on what the change would have been.

\section{Jewish-Christian Relations}

For this section, I offer several questions that might help us focus conversation and that might lead to new studies.

1. How does the reclamation of Jesus by Jews, the focus on Jesus as a Jew, and the recognition that all of Jesus' immediate followers were Jews impact our understanding today of the various forms of Messianic Judaism?

2. How might understanding of Jesus as a first-century Jew who engages in the distinctive practices of this tradition help American, relatively secularized people, better appreciate such traditions as ritual purity, law as sanctification rather than as oppressive yoke, pilgrimage, and sense of communitarian religiosity? 
3. At the same time, might understanding Jesus as a first-century Jew help both Jews and Christians today recognize our common roots?

4. How might understandings of Jesus as a Jew help interreligious families (e.g., could the "Our Father" serve as a bridge between Christian grandparents and Jewish grandchildren); more broadly, could Jesus serve as a bridge rather than a wedge?

5. How might recognizing the vibrancy of Jewish culture at the time of Jesus, and Jesus' place within it, help in eliminating or correcting the anti-Jewish comments that continue to infect sermons, Bible studies, Sunday school curricula, and sometimes the classroom-and in turn, how might understanding Jesus as a Jew help in eliminating or correcting the anti-Christian comments that I have heard in synagogues, Torah study sessions, and Hebrew Schools?

We have much to discuss. On the Jubilee year of Vatican II, how appropriate that a Catholic institution welcomes a gathering of Catholics, Protestants, Jews, and others, to discuss in a context of religious respect, academic rigor, and pastoral concern, Jesus, Judaism, and Jewish-Christian relations. My thanks to the conveners of this program, to Xavier University for this hospitality, and to Professor Dewey for his palpable commitment to the concerns that occupied the prophets of Israel and Jesus of Nazareth. We do not reconstruct the history the same way, and we do not see Jesus through the same lenses. I would like to think that the ongoing work in which we engage is, as the rabbis put it, "a controversy waged in the service of God" (Pirke Avot 5.20). And I would like to think that Jesus the Jew will become someone recognized by Jews and Christians both, with both "Jesus" and "Jew" understood respectfully, generously, and historically. 